\title{
Peran Kepercayaan Terhadap Penggunaan Pengobatan Tradisional Pada Penderita Hipertensi Di Kota Bengkulu
}

\section{Practical Beliefs on Traditional Treatment among Patients with Hypertension in Bengkulu City}

\section{Lissa Ervina, Dian Ayubi}

Departemen Pendidikan Kesehatan dan Ilmu Perilaku, Fakultas Kesehatan Masyarakat Universitas Indonesia

\begin{abstract}
ABSTRAK
Latar Belakang. Hipertensi merupakan masalah kesehatan serius yang menyebabkan kematian. Hasil Riset Kesehatan Dasar 2013 menunjukkan 21,6\% masyarakat Bengkulu menderita hipertensi. Provinsi Bengkulu menempati posisi 10 besar provinsi yang paling banyak penderita rawat jalan pada pengobatan tradisional setahun terakhir termasuk penderita hipertensi.

Tujuan. Penelitian ini bertujuan untuk mengetahui pengaruh kepercayaan penderita terhadap penggunaan pengobatan tradisional setelah faktor karakteristik sosial demografi dikendalikan di wilayah kerja Puskesmas Nusa Indah Kota Bengkulu.

Metode. Rancangan penelitian yang dipakai adalah studi potong lintang dengan melakukan survey pada 190 responden yang dipilih secara acak. Wawancara dilakukan dengan menggunakan kuesioner. Analisa multivariat dilakukan dengan menggunakan model regresi logistik ganda.

Hasil. Penelitian ini menemukan bahwa $66,8 \%$ penderita hipertensi menggunakan pengobatan tradisional. Nilai rerata variabel kepercayaan adalah 56,2 (skala 100). Dalam analisis bivariat menggunakan kai kuadrat, variabel kepercayaan berhubungan signifikan dengan penggunaan pengobatan tradisional. Namun berdasarkan analisis multivariat, variabel kepercayaan tidak mempengaruhi penggunaan pengobatan tradisional melainkan variabel pendidikan yang berpengaruh.
\end{abstract}

Kata kunci: rawat jalan, darah tinggi, kepercayaan, pengobatan tradisional, hipertensi

\section{ABSTRACT}

Background. Hypertension is a serious disease that causes death. In 2013, the National Basic Health Research showed 21,6\% of Bengkulu City people have hypertension. Bengkulu Province is one of ten provinces which have greater number of traditional treatment outpatient including hypertension.

Aim. This study aim is to access effect of believe to usage of traditional treatments among hypertension patient after controlling social demography characteristics.

Method. The study selected randomly 190 respondents and interviewed them using questionnaire. All respondents is hypertension patients who visited Nusa Indah community health center in last six months. Data were analyzed used multiple logistic regression based on computer software.

Result. The study found 66,8\% respondents used multiple traditional treatment. Mean score of respondent's believe in 56,2 (scale 100). In multivariate analysis, there is no statistically significant between respondent's believe and traditional treatment usage. Meanwhile, respondent's educational background has significant relationship to traditional treatment usage.

Keyword: outpatient, blood pressure, faith, traditional treatment, hypertension 


\section{LATAR BELAKANG}

Hipertensi diperkirakan menjadi penyebab 7,5 juta kematian atau sekitar 12,8\% dari total kematian per tahun di seluruh dunia ${ }^{1}$. Persentase penderita hipertensi paling banyak di negara berkembang yaitu sebesar $40 \%$, sedangkan negara maju sekitar 35\% ${ }^{2}$. Pada tahun 2013, prevalensi hipertensi di Indonesia yang didapat melalui pengukuran pada umur lebih dari 18 tahun sebesar 25,8\% ${ }^{3}$.

Tingginya kejadian hipertensi diikuti dengan peningkatan perilaku pencarian pengobatan di masyarakat. Akan tetapi kenyataannya tidak semua masyarakat memanfaatkan fasilitas kesehatan modern, mereka lebih memilih pengobatan tradisional. Ching et al. menemukan $62,6 \%$ penderita hipertensi di Malaysia menggunakan pengobatan alternatif dan komplementer dalam mengatasi hipertensi ${ }^{4}$. Hal ini serupa dengan hasil penelitian di Uganda bahwa ada terdapat $56,2 \%$ penderita hipertensi pernah menggunakan pengobatan alternatif ${ }^{5}$. Di Turki, sebanyak $51,3 \%$ penderita hipertensi menggunakan pengobatan tradisional jenis terapi herbal untuk mengobati hipertensinya ${ }^{6}$.

Pada tahun 2008, Provinsi Bengkulu termasuk 10 besar dari 33 provinsi di Indonesia yang masyarakatnya menjalani rawat inap-jalan di pengobat tradisional (battra) dalam satu tahun terakhir ${ }^{7}$. Di Kota Bengkulu, pada masyarakat yang menggunakan penggunaan pengobatan tradisional, $62 \%$ masyarakat memilih pengobatan alternatif metode keterampilan seperti tukang pijat, pijat refleksi, dan sinshe akupuntur, sedangkan yang memilih metode ramuan sebanyak $38 \%{ }^{8}$. Di Puskesmas Nusa Indah Kota Bengkulu, terdapat peningkatan jumlah kunjungan masyarakat ke battra yang ada di wilayah kerja Puskesmas Nusa Indah yaitu sebanyak 4276 kunjungan pada tahun 2011 menjadi 5380 kunjungan pada tahun 2012. Keluhan kesehatan pada kunjungan tersebut antara lain hipertensi, diabetes, jantung, stroke, rematik. Jumlah penderita hipertensi merupakan penyakit tertinggi dari 10 penyakit terbanyak di wilayah kerja Puskesmas Nusa Indah.

Beberapa hasil penelitian sebelumnya menyatakan bahwa beberapa faktor yang berhubungan dengan pemanfaatan pengobatan tradisional yaitu umur, jenis kelamin, pendidikan ${ }^{9}$, pekerjaan10, pendapatan ${ }^{11}$, sikap ${ }^{12}$, dan pengetahuan, ketersediaan, kepercayaan ${ }^{13}$. Penelitian ini bertujuan mengetahui pengaruh kepercayaan terhadap pemanfaatan pengobatan tradisional pada penderita hipertensi setelah karakteristik sosial demografi dikendalikan. Karakteristik sosial demografi mencakup umur, jenis kelamin, pendidikan, pekerjaan, pendapatan.

\section{METODE}

Penelitian ini menggunakan pendekatan kuantitatif dengan rancangan cross sectional. Pengumpulan data dilakukan pada April-Mei 2014. Populasi penelitian adalah seluruh penderita hipertensi di wilayah kerja Puskesmas Nusa Indah Kota Bengkulu yang mencakup empat kelurahan yaitu Kelurahan Tanah Patah, Kelurahan Nusa Indah, Kelurahan Kenanga, dan Kelurahan Kebun Beler.

Penghitungan besar sampel dilakukan dengan menggunakan software sample size determination in health studies dan menggunakan desain efek sebesar dua. Sampel penelitian diambil dengan cara menggunakan simple random sampling. Kerangka sampel merupakan data penderita hipertensi dalam kurun waktu enam bulan terakhir yang didapatkan dari rekam medik pasien di Puskesmas Nusa Indah. Sampel penelitian diperoleh dengan cara acak menggunakan program di website www.random.org.

Wawancara menggunakan kuesioner dilakukan terhadap 190 reponden. Pewawancara adalah mahasiswi keperawatan. Instrument diujicobakan terlebih dahulu untuk mengetahui validitas dan realibilitas. Uji coba instrument 
dilakukan kepada 30 responden di wilayah kerja Puskesmas Sawah Lebar yang memiliki kriteria sama dengan sampel yang digunakan dalam penelitian ini. Uji validitas kuesioner menggunakan uji korelasi Pearson (r), untuk total sampel 30 , df $=\mathrm{N}-2=30-2=28$, maka didapatkan nilai $r$ adalah 0,374. Variabel pemanfaatan pengobatan tradisional diukur berdasarkan praktik atau tindakan nyata responden dalam melakukan pencarian pengobatan alternatif untuk mengatasi hipertensi dalam kurun waktu enam bulan terakhir dengan cara berkunjung ke pengobatan tradisional, baik scara keterampilan, ramuan, dan atau pendekatan agama.

Analisis multivariate menggunakan uji regresi logistik ganda untuk mengetahui pengaruh variabel independen dan variabel dependen secara bersamaan dan untuk mencari faktor yang paling dominan dalam pemanfaatan pengobatan tradisional. Untuk seleksi variabel kandidat pada analisis multivariat digunakan analisis chi-square. Variabel akan menjadi kandidat jika nilai $\mathrm{p}<0,05$.

\section{HASIL}

Tabel 1. Distribusi Rsponden Menurut Penggunaan Pengobatan Tradisonal pada Penderita Hipertensi di Wilayah Kerja Puskesmas Nusa Indah Kota Bengkulu Tahun 2014 (n = 190)

\begin{tabular}{|c|c|c|}
\hline Penggunaan Pengobatan Tradisional & $\mathbf{n}$ & $\%$ \\
\hline $\begin{array}{l}\text { Penggunaan Pengobatan Tradisional: } \\
-\quad \text { Tidak } \\
-\quad \text { Ya }\end{array}$ & $\begin{array}{c}63 \\
127\end{array}$ & $\begin{array}{l}33.2 \\
66.8 \\
\end{array}$ \\
\hline $\begin{array}{l}\text { Frekuensi Penggunaan Pengobatan Tradisional Dalam Sebulan Terakhir (n } \\
\begin{aligned}=76) & \\
- & 1 \text { kali } \\
- & 2 \text { kali } \\
- & \geq 3 \text { kali }\end{aligned}\end{array}$ & $\begin{array}{l}21 \\
30 \\
25\end{array}$ & $\begin{array}{l}27.6 \\
37.5 \\
32.9\end{array}$ \\
\hline $\begin{aligned} \text { Jenis } & \text { Pengobat Tradisional }(\mathrm{n}=127) \\
- & \text { Tukang urut } \\
- & \text { Dukun } \\
- & \text { Akupunturis } \\
- & \text { Tukang jamu } \\
- & \text { Herbalis }\end{aligned}$ & $\begin{array}{l}85 \\
75 \\
56 \\
52 \\
46\end{array}$ & $\begin{array}{l}66.9 \\
59.1 \\
44.1 \\
40.9 \\
36.2\end{array}$ \\
\hline $\begin{aligned} & \text { Cara Pengobatan Tradisional }(\mathrm{n}=127) \\
&- \text { Pijat urut } \\
&- \text { Ramuan/herbal } \\
&- \text { Akupuntur } \\
&- \text { Akupressor } \\
&- \text { Konsumsi jamu } \\
&\end{aligned}$ & $\begin{array}{c}101 \\
78 \\
78 \\
74 \\
71 \\
\end{array}$ & $\begin{array}{l}79.5 \\
61.4 \\
61.4 \\
58.3 \\
55.9 \\
\end{array}$ \\
\hline
\end{tabular}

Tabel 1 memperlihatkan bahwa $66.8 \%$ responden menggunakan pengobatan tradisional untuk menyembuhkan hipertensi yang dideritanya. Sebanyak $32.9 \%$ telah menggunakan pengobatan tradisional lebih atau sama dengan 3 kali dalam sebulan terakhir. Sebanyak $66.9 \%$ responden memilih tukang urut sebagai pengobat tradisional. 
Tabel 2 Distribusi Responden Menurut Karakteristik Sosial Demografi pada Penderita Hipertensi di Wilayah Kerja Puskesmas Nusa Indah Kota Bengkulu Tahun $2014(\mathbf{n}=190)$

\begin{tabular}{|c|c|c|}
\hline Karakteristik Sosial Demografi & $\mathbf{N}$ & $\%$ \\
\hline $\begin{array}{l}\text { Umur ( } \text { median }=55 \text { tahun, min }=33 \text { tahun, maks }=78 \text { tahun }) \\
\quad-\quad<55 \text { tahun } \\
\quad-\quad \geq 55 \text { tahun }\end{array}$ & $\begin{array}{l}93 \\
97\end{array}$ & $\begin{array}{l}48.9 \\
55.3\end{array}$ \\
\hline $\begin{aligned} \text { Jenis } & \text { Kelamin } \\
- & \text { Laki-laki } \\
- & \text { Perempuan }\end{aligned}$ & $\begin{array}{c}85 \\
105\end{array}$ & $\begin{array}{l}44.7 \\
55.3\end{array}$ \\
\hline $\begin{array}{cc}\text { Status } & \text { Perkawinan } \\
- & \text { Menikah }\end{array}$ & 190 & 100.0 \\
\hline $\begin{array}{cl}\text { Pendidikan } \\
\text { - } & \text { Tidak sekolah } \\
\text { - } & \text { Tamat SD/sederajat } \\
\text { - } & \text { Tamat SMP/sederajat } \\
\text { - } & \text { Tamat SMA/sederajat } \\
\text { - } & \text { Tamat Perguruan Tinggi }\end{array}$ & $\begin{array}{l}10 \\
11 \\
32 \\
87 \\
50\end{array}$ & $\begin{array}{c}5.3 \\
5.8 \\
16.8 \\
45.8 \\
26.3\end{array}$ \\
\hline $\begin{aligned} & \text { Status } \text { Pekerjaan } \\
&- \text { Bekerja } \\
&- \text { Tidak bekerja } \\
&\end{aligned}$ & $\begin{array}{c}129 \\
61 \\
\end{array}$ & $\begin{array}{l}67.9 \\
32.1 \\
\end{array}$ \\
\hline $\begin{aligned} & \text { Pendapatan per bulan } \\
& \quad- \geq \mathrm{Rp} 1.447 .674 \text { (UMR Kota Bengkulu) } \\
&-<\mathrm{Rp} 1.447 .674\end{aligned}$ & $\begin{array}{c}117 \\
73\end{array}$ & $\begin{array}{l}61.6 \\
38.4\end{array}$ \\
\hline $\begin{aligned} \text { Pengetahuan }(\text { rerata }=6 ; \min =2.2 ; \text { maks }=10) \\
-\quad \text { Tinggi }(\geq \text { nilai } 6.0) \\
-\quad \text { Rendah }(<\text { nilai } 6.0)\end{aligned}$ & $\begin{array}{l}93 \\
97 \\
\end{array}$ & $\begin{array}{l}48.9 \\
51.1\end{array}$ \\
\hline
\end{tabular}

Tabel 2 menjelaskan bahwa seluruh responden telah menikah dan $55.3 \%$ responden berjenis kelamin perempuan. Sebanyak $45.8 \%$ responden memiliki pendidikan terakhir tamat
SLTA/sederajat. Sebesar $51.5 \%$ responden berpengetahuan rendah mengenai pengobatan tradisional. 
Tabel 3 Distribusi Responden Menurut Kepercayaan terhadap Pengobatan Tradisional pada Penderita Hipertensi di Wilayah Kerja Puskesmas Nusa Indah Kota Bengkulu Tahun 2014 (n= 190)

\begin{tabular}{|c|c|c|}
\hline Butir-Butir Kepercayaan & $\mathbf{n}$ & $\%$ \\
\hline $\begin{array}{l}\text { Percaya hipertensi sembuh dengan cara pengobatan tradisional } \\
\text { Tidak percaya } \\
\text { Kurang percaya } \\
\text { Percaya }\end{array}$ & $\begin{array}{c}31 \\
53 \\
106\end{array}$ & $\begin{array}{l}16.3 \\
27.9 \\
55.8\end{array}$ \\
\hline $\begin{array}{l}\text { Merasa asing ketika melakukan pengobatan tradisional } \\
\text { Asing } \\
\text { Kadang asing } \\
\text { Tidak asing }\end{array}$ & $\begin{array}{l}26 \\
72 \\
92 \\
\end{array}$ & $\begin{array}{l}13.7 \\
37.9 \\
48.4 \\
\end{array}$ \\
\hline $\begin{array}{l}\text { Perasaan terhadap hasil pengobatan tradisional dalam mengatasi hipertensi } \\
\text { Tidak memuaskan } \\
\text { Kurang memuaskan } \\
\text { Memuaskan }\end{array}$ & $\begin{array}{l}39 \\
93 \\
58\end{array}$ & $\begin{array}{l}20.5 \\
48.9 \\
30.5\end{array}$ \\
\hline $\begin{array}{l}\text { Jenis penyakit bisa diobati dengan pengobatan tradisional } \\
\text { Tidak satu pun jenis penyakit } \\
\text { Hanya beberapa jenis penyakit } \\
\text { Semua jenis penyakit }\end{array}$ & $\begin{array}{l}28 \\
94 \\
68 \\
\end{array}$ & $\begin{array}{l}14.7 \\
49.5 \\
35.8 \\
\end{array}$ \\
\hline $\begin{array}{l}\text { Melakukan pengobatan tradisional selalu pada orang yang sama } \\
\text { Tidak } \\
\text { Kadang-kadang } \\
\text { Ya }\end{array}$ & $\begin{array}{l}25 \\
93 \\
72\end{array}$ & $\begin{array}{l}13.2 \\
48.9 \\
27.9\end{array}$ \\
\hline $\begin{array}{l}\text { Pengalaman yang menjadi alasan paling mendasari percaya terhadap } \\
\text { pengobatan tradisional } \\
\text { Pengalaman pribadi } \\
\text { Pengalaman keluarga } \\
\text { Pengalaman teman } \\
\text { Pengalaman tetangga } \\
\text { Pengalaman orang lain di media cetak dan TV }\end{array}$ & $\begin{array}{c}78 \\
121 \\
68 \\
101 \\
116\end{array}$ & $\begin{array}{l}41.1 \\
63.7 \\
35.8 \\
53.2 \\
61.1\end{array}$ \\
\hline $\begin{array}{l}\text { Kelebihan pengobatan tradisional sehingga percaya terhadap pengobatan } \\
\text { tradisional } \\
\text { Murah } \\
\text { Aman } \\
\text { Cepat sembuh } \\
\text { Praktis } \\
\text { Lain-lain }\end{array}$ & $\begin{array}{l}126 \\
120 \\
111 \\
87 \\
13\end{array}$ & $\begin{array}{r}66.3 \\
63.2 \\
58.4 \\
45.8 \\
6.8\end{array}$ \\
\hline
\end{tabular}

Dari Tabel 3 diketahui bahwa $55.8 \%$ responden menyatakan percaya bahwa hipertensi dapat sembuh dengan pengobatan tradisional. Sebanyak $63.7 \%$ responden menyatakan pengalaman keluarga sebagai alasan kenapa mempercayai pengobatan tradisional. Sejumlah $66.3 \%$ responden menyatakan bahwa harga yang murah menjadi kelebihan pengobatan tradisional. 
Tabel 4 Distribusi Responden Menurut Kepercayaan, Pengetahuan, Karakteristik Sosial Demografi dan Penggunaan Pengobatan Tradisional pada Penderita Hipertensi di Wilayah Kerja Puskesmas Nusa Indah Kota Bengkulu Tahun $2014(n=190)$

\begin{tabular}{|c|c|c|c|c|c|c|c|}
\hline \multirow{3}{*}{ Variabel } & \multicolumn{4}{|c|}{ Pengobatan Tradisional } & \multirow{2}{*}{\multicolumn{2}{|c|}{ Total }} & \multirow{3}{*}{ Nilai $\mathrm{p}$} \\
\hline & \multicolumn{2}{|c|}{$\mathrm{Ya}$} & \multicolumn{2}{|c|}{ Tidak } & & & \\
\hline & $\mathbf{n}$ & $\%$ & $\mathbf{n}$ & $\%$ & $\mathbf{n}$ & $\%$ & \\
\hline \multicolumn{8}{|l|}{$\begin{array}{l}\text { Kepercayaan: }(\text { rerata }=56.3 ; \min =20 ; \text { maks }= \\
\text { 90) }\end{array}$} \\
\hline - Tinggi & 75 & 74.3 & 26 & 25.7 & 101 & 100.0 & 0.03 \\
\hline - Rendah & 52 & 58.4 & 37 & 41.6 & 89 & 100.0 & \\
\hline \multicolumn{8}{|l|}{ Jenis Kelamin: } \\
\hline - Perempuan & 70 & 66.7 & 35 & 33.3 & 105 & 100.0 & 1.00 \\
\hline - Laki-laki & 57 & 67.1 & 28 & 32.9 & 85 & 100.0 & \\
\hline \multicolumn{8}{|l|}{ Umur: } \\
\hline$-\quad \geq 55$ tahun & 63 & 64.9 & 34 & 35.1 & 97 & 100.0 & 0.64 \\
\hline$-\quad<55$ tahun & 64 & 68.9 & 29 & 31.2 & 93 & 100.0 & \\
\hline \multicolumn{8}{|l|}{ Pekerjaan: } \\
\hline - Tidak bekerja & 44 & 72.1 & 17 & 27.9 & 61 & 100.0 & 0.33 \\
\hline - Bekerja & 83 & 64.3 & 46 & 35.7 & 129 & 100.0 & \\
\hline \multicolumn{8}{|l|}{ Lama Menderita Hipertensi: } \\
\hline$-\quad \geq 7$ tahun & 57 & 69.5 & 25 & 30.5 & 82 & 100.0 & 0.54 \\
\hline$-\quad<7$ tahun & 70 & 64.8 & 38 & 35.2 & 108 & 100.0 & \\
\hline \multicolumn{8}{|l|}{ Pendidikan: } \\
\hline - Di bawah SLTP/sederajat & 43 & 81.1 & 10 & 18.9 & 53 & 100.0 & 0.01 \\
\hline - SMA dan Perguruan Tinggi & 84 & 61.3 & 53 & 38.7 & 137 & 100.0 & \\
\hline \multicolumn{8}{|l|}{ Pengetahuan: } \\
\hline - Tinggi & 63 & 67.7 & 30 & 34.0 & 93 & 100.0 & 0.92 \\
\hline - $\quad$ Rendah & 64 & 66.0 & 33 & 32.3 & 97 & 100.0 & \\
\hline
\end{tabular}

Tabel 4 menunjukkan bahwa pada responden yang memiliki kepercayaan tinggi terhadap pengobatan tradisional, $74.3 \%$ menggunakan pengobatan tradisional dan $25.7 \%$ tidak menggunakan pengobatan tradisional. Di kelompok responden berpendidikan rendah, $81.1 \%$ menggunakan pengobatan tradisional dan $18.9 \%$ tidak menggunakan pengobatan tradisional. Hasil uji kai kuadrat memberikan nilai p kurang 0.05 untuk variabel kepercayaan dan pendidikan.

Selanjutnya dilakukan uji regresi logistic ganda dengan melibatkan variabel pemanfaatan pengobatan tradisional sebagai variabel terikat, kepercayaan sebagai variabel bebas dan variabel pengganggu yang memenuhi syarat sebagai variabel kandidat (nilai $p>0.25$ ) adalah variabel pendidikan, dengan hasil sebagai berikut: 
Tabel 5. Hasil Uji Regresi Logistik Ganda untuk Penggunaan Pengobatan Tradisional pada Penderita Hipertensi di Wilayah Kerja Puskesmas Nusa Indah Kota Bengkulu Tahun 2014 (n= 190)

\begin{tabular}{|l|l|l|l|l|l|}
\hline Pengobatan Tradisional & B & S.E & Wald & Nilai $\mathrm{p}$ & Exp (B) \\
\hline Intercept & -0.78 & 0.25 & 9.49 & 0.002 & \\
\hline Pendidikan & -0.88 & 0.40 & 4.79 & 0.028 & 0.42 \\
\hline Kepercayaan & 0.59 & 0.32 & 3.33 & 0.069 & 1.79 \\
\hline
\end{tabular}

Tabel 5 menginformasikan bahwa berdasarkan uji regresi logistik ganda variabel pendidikan memiliki nilai $\mathrm{p}$ sebesar 0.028 dan variabel kepercayaan memiliki nilai $\mathrm{p}$ sebesar 0.069 .

\section{DISKUSI}

Penelitian ini menemukan bahwa $66.8 \%$ penderita hipertensi menggunakan pengobatan tradisional dalam enam bulan terakhir. Jumlah frekuensi kunjungan penderita hipertensi yang rutin memanfaatkan pengobatan tradisional dalam satu bulan bisa bervariasi antara lain satu kali dalam sebulan (27.6\%), dua kali dalam sebulan (39.5\%), tiga kali dalam sebulan $(21.1 \%)$, dan lebih dari tiga kali dalam sebulan (11.8\%). Menurut hasil penelitian Santoso et al. (2001) di Yogyakarta bahwa penderita hipertensi melakukan kunjungan ke pengobatan tradisional (battra) sebanyak 2-4 kali sebesar 66.7\%.

Andel dan Carvalheiro (2013) yang melakukan penelitian penggunaan obat tradisional di Suriname mendapatkan bahwa $66 \%$ masyarakat setempat menggunakan obat tradisional dalam satu tahun terakhir, dengan keluhan sakit batuk pilek, demam, hipertensi, sakit kepala, gangguan pada rahim dan gangguan pada saluran kencing. Ching et al. (2013) dalam penelitiannya di Malaysia menyatakan bahwa penggunaan pengobatan alternatif dan komplementer pada penderita hipertensi sebesar 62.6\%. Hasil penelitian Bahar et al. (2013) di Turki juga mendapatkan bahwa pasien hipertensi yang menggunakan terapi herbal dalam mengatasi hipertensi sebesar $51.3 \%$. Kemudian Nugawa dan Musinguzi
(2013) juga melakukan penelitian di Uganda dan mendapatkan bahwa penderita hipertensi yang menggunakan pengobatan alternatif sebesar $56.2 \%$.

WHO menyatakan bahwa tiga karakteristik pengobatan tradisional yang membuat pasien percaya terhadap pengobatan tradisional adalah pertama, kepercayaan bahwa hidup adalah kesatuan dari badan, emosi, pikiran dan roh atau jiwa, dan kesehatan adalah keseimbangan antara beberapa aspek di dalam badan manusia dengan lingkungan. Penyakit akan terjadi bila tidak ada kesinambungan antara fisik, emosional, mental, atau spiritual. Kedua, pengobatan tradisional menggunakan pendekatan menyeluruh pada diagnosis dan tindakan, bukan melihat bagian per bagian tubuh. Ketiga, pengobatan tradisional berdasarkan pada kebutuhan individu, berbeda orang berbeda tindakan meskipun pada kasus penyakit yang sama ${ }^{14}$.

Penelitian ini menemukan bahwa 68,4\% penderita hipertensi memiliki kepercayaan tinggi terhadap pengobatan tradisional. Sebanyak $55.8 \%$ responden percaya hipertensi bisa sembuh dengan cara pengobatan tradisional. Hal ini berbeda dengan penelitian di Yogyakarta, sebesar $75.7 \%$ penderita hipertensi percaya hipertensi bisa sembuh dengan melakukan pengobatan tradisional ${ }^{15}$.

Meskipun dalam analisis bivariat, kepercayaan berhubungan signifikan dengan penggunaan pengobatan tradisional, namun dalam analisis multivariat didapat kepercayaan tidak mempengaruhi penggunaan pengobatan tradisional. Hal ini tidak sejalan dengan penelitian Mulyadi (2005) bahwa kepercayaan 
ada hubungannya dengan pengobatan tradisional herbalis, dimana orang dengan tingkat kepercayaan tinggi memiliki peluang 2.58 kali lebih besar menggunakan pengobatan tradisional herbalis dibanding orang dengan kepercayaan rendah.

Variabel pendidikan terlihat berhubungan signifikan dalam mempengaruhi responden dalam menggunakan pengobatan tradisional. Menurut Andersen (1995), pendidikan merupakan bagian dari struktur sosial yang menjadi faktor predisposisi seseorang dalam berperilaku dalam memanfaatkan fasilitas kesehatan. Penelitian ini mendapatkan bahwa penderita hipertensi berpendidikan rendah yang memanfaatkan pengobatan tradisional sebesar $81.1 \%$. Gitawati, Nugroho, dan Winarno (2008) menemukan bahwa tingkat pendidikan rendah lebih banyak berobat ke pengobat tradisional. Supardi dan Susyanti (2010) juga menyatakan bahwa tingkat pendidikan rendah proporsisinya lebih tinggi dalam menggunakan obat tradisional. Berbeda dengan hasil penelitian Chi et al. (2012), Birhan et al. (2011) bahwa pendidikan tinggi lebih sering berkunjung ke pengobat tradisional.

\section{Kesimpulan}

1. Sebanyak $66.8 \%$ penderita hipertensi menggunakan pengobatan tradisional. Sebagian besar responden berumur $\geq 55$ tahun, berjenis kelamin perempuan dan berpendidikan tinggi.

2. Sebanyak $68.4 \%$ penderita hipertensi memiliki kepercayaan tinggi terhadap pengobatan tradisional. Pengalaman keluarga dan biaya murah menjadi alasan yang paling banyak dinyatakan oleh penderita ketika memilih pengobatan tradisional.

3. Faktor-faktor yang berhubungan dengan penggunaan pengobatan tradisional pada penderita hipertensi adalah pendidikan dan kepercayaan.
4. Kepercayaan bukan merupakan variabel yang dominan, melainkan tingkat kependidikan penderita yang mempengaruhi penggunaan pengobatan tradisional.

\section{Saran}

1. Dinas Kesehatan Kota Bengkulu perlu melakukan upaya peningkatan kesadaran tentang efektifitas pengobatan tradisional dalam pengobatan hipertensi kepada masyarakat, kader, battra, dan petugas kesehatan.

2. Dinas Kesehatan Kota Bengkulu perlu meningkatkan pengawasan dan perizinan terhadap pengobatan tradisional.

\section{Daftar Referensi}

${ }^{1}$ Global Status Report on Noncommunicable Disease $2010 . \quad$ WHO.

(2011). http://www.who.int/nmh/publications/ncd_rep ort_full_en.pdf

${ }^{2}$ WHO. (2011). Noncommunicable Disease, Country Profiles 2011. http://whqlibdoc.who.int/publications/2011/97 $\underline{89241502283 \text { eng.pdf }}$

${ }^{3}$ Litbangkes. (2013). Riset Kesehatan Dasar, RISKESDAS 2013. Badan Penelitian dan Pengembangan Kesehatan, Kementerian Kesehatan RI. Jakarta

${ }^{4}$ Ching, Vasudevan, Zakaria, and Paimin. (2013). Frequency of complementary and alternative medicine usage among Malaysian Hypertensive subjects. Life Science Journal 2013; 10(4)

${ }^{5}$ Nuwaha and Musinguzi. (2013). Use of Alternative Medicine for Hypertension in Buikwe and Mukono District of Uganda: a Cross Sectional Study. BMN Complementary and Alternative Medicine. 13:301

${ }^{6}$ Bahar. (2013). Herbal Therapies Used by Hypertensive Patients in Turkey. Afr $J$ Traditional Complementer Alternatif Medikal: 10(2):292-298 
${ }^{7}$ Gitawati, Nugroho \& Winarno. (2008). Gambaran Pemanfaatan Pengobat Tradisional dan Hubungannya dengan Akses Pelayanan Kesehatan di Indonesia. Laporan Analisis Lanjut. Puslitbang Biomedis dan Farmasi. Depkes. Jakarta

${ }^{8}$ Herlina. (2011). Faktor-Faktor yang Berhubungan dengan Pemilihan Jenis Pengobatan Alternatif pada Masyarakat Pengguna Pengobatan Alternatif di Kota Bengkulu Tahun 2001. Tesis. Fakultas Kesehatan Masyarakat. Universitas Indonesia.

${ }^{9}$ Supardi, Herman \& Susyanti. (2009). Pengobatan Sendiri Pada Pasien Rawat Jalan Puskesmas di Delapan Kabupaten. Buletin Penelitian Kesehatan. Vol.37, No.2, 2009 : 92-101.

${ }^{10}$ Anggraini. (2004). Analisis Faktor-Faktor yang Berhubungan dengan Tingkat Penggunaan Pengobatan Tradisional di Klinik Konsultasi dan Pengobatan Tradisional "Gus Muhammad Al-Karomah" Klender Jakarta Timur Tahun 2004. Skripsi. Fakultas Kesehatan Masyarakat. Universitas Indonesia
${ }^{11}$ Lim et al. (2005). Complementary and Alternative Medicine Use in Multiracial Singapore. Complementary Therapies in Medicine (2005) $13,16-24$.

${ }^{12}$ Idem no.8

${ }^{13}$ Mulyadi. (2005). Analisis Faktor-Faktor yang Mempengaruhi Keluarga Menggunakan Pengobatan Tradisional Herbalis dalam Mengatasi Masalah Kesehatan di Dewa Warujaya Parung Bogor. Tesis. Fakultas Ilmu Keperawatan. Universitas Indonesia.

${ }^{14}$ Jauhari, Utami, dan Padmawati. (2008). Motivasi dan Kepercayaan Pasien untuk Berobat ke Sinse. Berita Kedokteran Masyarakat. Vol.24, No.1, Maret 2008.

${ }^{15}$ Santoso, Prasodjo, dan Zalbawi. (2001). FaktorFaktor yang Mendorong Penderita Hipertensi ke Pengobatan Tradisional di DKI Jakarta, Yogyakarta, dan Surabaya. Media Litbang Kesehatan. Volume XI Nomor 1 